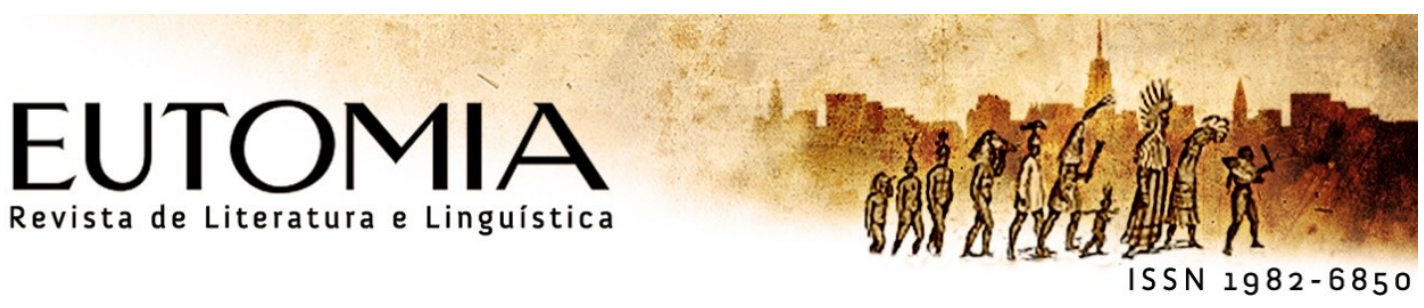

\title{
From morning to mourning: Yanomami listening practices in A Queda do céu
}

\section{Da iniciação ao luto: práticas da escuta Yanomami em A Queda do Céu}

William Mullaney ${ }^{i}$ (Princeton University)

\begin{abstract}
In Davi Kopenawa and Bruce Albert's A Queda do céu, listening, within the context of Yanomami shamanism, entails transposing the words of Omama, the creator god, and his spirits, the xapiri into the present, with the aim of establishing a livable future. This text, with its complex questions of co-authorship, demands of the reader a kind of listening in order to open up to Yanomami forms of sense-making. Shamanic listening depends on an initiation ceremony, which is a "listening lesson" as much for Kopenawa as for the reader. The undecidable nexus of hearing/imitating is the grounds for the discovery of the otherness of the self, a self-difference from which meaning stems. The shamanic listening practice is embedded within collective political struggles emerging in resistance to the colonizing incursions of market capitalism. Matihi is the name the Yanomami give to commodities, as they integrate them into a system of exchange involving affect and interdependence. Matihi, connected to mortality and the forest's lived past, illustrates the renewal process born of shamanic listening.
\end{abstract}

Keywords: Davi Kopenawa; Bruce Albert; listening; anthropology.

Resumo: Em A Queda do Céu de Davi Kopenawa e Bruce Albert, a escuta, dentro do contexto do xamanismo yanomami, envolve a transposição das palavras de Omama, o deus criador, e dos seus espíritos, os xapiri, ao presente, com o alvo de estabelecer um futuro habitável. O texto, com as suas questões complexas de co-autoria, exige do leitor uma forma de escuta aberta às formas yanomami de gerar sentidos (sens). A escuta xamânica depende de uma cerimônia de iniciação, que é uma "lição de escuta" tanto para Kopenawa como para o leitor. O nexo indecidível do escutar/imitar é a base da descoberta da alteridade do eu, auto-diferença do qual se origina o sentido (sens). A escuta xamânica é conectada à luta 
política coletiva que resiste às incursões do capitalismo mercantil. Matihi é o nome que os Yanomami dão às mercadorias, para integrá-las dentro de um sistema de troca que envolve o afeto e a interdependência. Matihi, conectado à mortalidade e ao passado da floresta, ilustra o processo de renovação da escuta xamânica.

Palavras-chave: Davi Kopenawa; Bruce Albert; escuta; antropologia.

Within the context of Yanomami shamanism, listening is rooted at once in the relationship the Yanomami have constructed over many generations with the forest that surrounds them, and in the shamans' interpretation of that relationship via the words of Omama. By "interpretation," I am referring to the shamanic practice of experiencing and embodying - or as Kopenawa says, "renewing"-the songs and dances of the creator, Omama, and his spirit messengers, the xapiri. "As palavras dos xapiri estão gravadas no meu pensamento, no mais fundo de mim. São as palavras de Omama. São muito antigas, mas os xamãs as renovam o tempo todo" (KOPENAWA, 2010, p. 65). Omama's words have been forged in the temporal depths of the mutual shaping of people and forest whose result is the Amazonian ecosystem. Kopenawa arrives at those words by looking "in the depths of me": a path forward into a collective future is only available insofar as the search directed inward toward an unknown self. The shamanic self is the seat of futurity. As Kopenawa writes, "São as antigas palavras de Omama. O que vocês chamam de futuro, para nós, é isso" (KOPENAWA, 2010, p. 506). Here, Kopenawa reveals the essence of the multi-directional temporal structure which shamanic becoming instantiates. Alice in Wonderland has a similar sense of becoming, which Deleuze describes: "Ouand je dis 'Alice grandit', je veux dire qu'elle devient plus grande qu'elle n'est maintenant. Mais par là-même aussi, elle devient plus petite qu'elle n'est maintenant. Bien sûr, ce n'est pas en même temps qu'elle est plus grande et plus petite. Mais c'est en même temps qu'elle le devient" (DELEUZE, 1969, p.9). Like Alice through the looking glass, shamanic becoming progresses simultaneously in opposite directions-at once toward an immense Other whose words resonate through the xapiri with the infinite renewal of the forest; and toward a collective future in that forest's regeneration.

When I say this practice is inextricably linked to the forest ecology, I mean that the regeneration process, whereby the deep past becomes the future, is, according to Kopenawa, 
the fundamental meaning of the forest. For the forest, becoming is omni-directional, since it is pure generation. As Kopenawa explains: "Já a floresta, se não for destruída sem razão, não morre nunca. Não é como o corpo dos humanos. Ela não apodrece para depois desaparecer. Sempre se renova" (KOPENAWA, 2010, p.472). The shaman is a translator or conduit between the immortality of the forest and the mortality of the people. Omama's words are that infinite renewal, and thus imbue the Yanomami language with a deep origin and immortality. ${ }^{1}$

We can place shamanic listening within a spectrum of forest-listening practices that the Yanomami undertake collectively. Fundamentally, listening to the forest relates to the Yanomami sense-making process in an integrated way that my own alienation from such practices makes personally inconceivable (and here is the value of this text, as it opens them up to my imagination). This sense-making process is evident in Albert's description of a Yanomami trek through the forest, which is replete with constant conversation with the animals. ${ }^{2}$ This echo, the participatory form of being-with the natural soundscape is itself making sense. In these dialogues, the Yanomami gather meanings from their sonic environment not only about the immediate surroundings and the nearby fauna but also orient themselves within time. ${ }^{3}$ Sounds provide a "chronogram", teaching listeners about both short- and long-term events. Furthermore, many Yanomami terms for animals originate from the sound that animals make. Of the many sense-making processes born of corporeal listening in the forest, shamanic listening is the one, as we shall explore, in touch with the temporal ground zero, the originary time of sense-making.

I.

From the source-listener-Kopenawa as individual part of the Yanomami collective-a text emerges that opens up a space of resonance for the reader by situating itself in multiple spaces of rebound-between authors, worlds, cultural practices-and by offering itself as a text

\footnotetext{
1 "São as palavras de Omama e dos xapiri" [...] "Quero fazê-los escutar a voz dos xapiri, que ali brincam sem parar, dançando sobre seus espelhos resplandecentes" [...] "Meu único professor foi Omama. São as palavras dele, vindas dos meus maiores, que me tornaram mais inteligente. Minhas palavras não têm outra origem. Não envelhecerão como as que ficam coladas em peles de imagens tiradas de árvores mortas" (KOPENAWA, 2010, pp.64-65).

2 See "A Floresta Políglota," especially the section about heã.

${ }^{3}$ This is a characteristic the Yanomami share with many different Amazonian groups. See Menezes Bastos' discussion of the Kamayurá (10). This common trait is what we term "sonic perspectivism" discussed later.
}

Eutomia, Recife, 25(1): 1-16, Dez. 2019 
to be listened to. A Queda do céu is itself a document of the in-between, a testament to and education in the resonant space opened up by shamanic listening. Kopenawa explains that his ancestors have never spoken to the whites before. ${ }^{4}$ He decided to open up the words of Omama and the xapiri to foreigners because of his outrage at the waves of epidemics that various groups of whites have unleashed on his people. ${ }^{5}$ Born of rage, this text comes to occupy several interlocking in-betweens. It was conceived between Davi as individual and the Yanomami collective and between Davi as Yanomami representative and Bruce Albert, his anthropologist collaborator. Further, the text is the product of a long series of mediations. From its origin in Davi's outrage over a news show demonstrating the extent of destruction wreaked by garimpeiros in Yanomami rivers, it was created out of the over twenty years of audio recordings then subsequently translated and reformatted by Albert into textual form (of which the version discussed here is a Portuguese translation). ${ }^{6}$ This structure of vertiginous mediation resembles the temporal transformations of shamanic activity in general, bringing origin times from within his deep self into a collective present not yet arrived. Viveiros de Castro elaborates on the space the text opens up as a fundamental example of shamanism itself: "If shamanism is essentially a cosmic diplomacy devoted to the translation between ontologically disparate points of view, then Kopenawa's discourse is not just a narrative on particular shamanic contents-namely, the spirits which the shamans make speak and act-; it is a shamanic form in itself, an example of shamanism in action, in which a shaman speaks about spirits to Whites and equally about Whites on the basis of spirits, and both these things through a White intermediary" (VIVEIROS DE CASTRO, 2010). Kopenawa's text, then, is an active example of shamanism. Its place of enunciation is multiple and diffuse, between worlds which seem almost as incompatible as the immortal world that shamans bring into the mortal sphere by ceremony, yãkoana, and listening to Omama.

\footnotetext{
4 "Perguntavam-se apenas por que aquela gente estranha tinha subido os rios até eles. Conversavam bastante a respeito disso, mas suas palavras nunca saíram da floresta para serem ouvidas" (KOPENAWA, 2010, p.383).

${ }^{5}$ Davi received the name of the wasp spirit Arowë, the spirit who taught courage and rage to his people. This is the spirit that guides him when he speaks to white people about the destruction of his forest. See pp. 71-73 and 386387.

${ }^{6}$ On the mix of individual and collective experience, see Albert's prologue, 50 . Viveiros de Castro refers to the text as an "entrebiography" and emphasizes that neither Kopenawa nor Albert is exactly representative of the milieu they come from (this is exactly what allows the text to exist in between).
}

Eutomia, Recife, 25(1): 1-16, Dez. 2019 
From a Western perspective, anthropological experience can open up a space of communication between ontologically disparate points of view. Such an experience can be initiated by the anthropologist pushing her body to its limits in intersubjective field-work living with the other. Yet as this text demonstrates, such an opening can resonate outwards and include readers in this practice of being-with-the-other. ${ }^{7}$ This anthropological-shamanic mutual opening is something Kopenawa sought out in his relationship with Albert. When necessary, he took the responsibility of reminding the anthropologist that his presence among the Yanomami meant active intersubjective participation in Yanomami culture-that settling for passive, scientific observation is not enough. ${ }^{8}$ Both co-authors recognize one experience as a fundamental moment of linkage: Albert was taking flash photos of shamans as they communicated with xapiri, and Kopenawa intervened. As Albert writes,

Kopenawa, que tinha se aproximado de mim sem alarde, me fez tomar consciência da agressividade e inconveniência de meu frenesi de registro com algumas frases definitivas... 'Pare de pegar a imagem desses homens que estão virando espíritos! Os xapiri deles estão aqui, ainda que nem você nem eu possamos vê-los! Você vai emaranhar seus caminhos e eles vão se perder'. (KOPENAWA, 2010, p.527)

As shaman, Kopenawa brings Albert into the living reality of the xapiri and breaks down the wall of objectivity that prevented Albert from understanding his embodied and affective position within a shamanic ritual, which was capable of interfering in sacred relations. The text is an extension of that original intersubjective space Kopenawa created with Albert for many years.

A successful reading of Kopenawa's text-reading becomes listening-welcomes the other and distances the conscious self; it echoes the intersubjective space in which the text was

\footnotetext{
${ }^{7}$ Albert discusses pushing his body to its limit and only after beginning to understand the meaning of Yanomami culture in the closing section of this text (519).

8 Albert quotes Kopenawa to this effect: "Nós, índios, precisamos de antropólogos que tenham coragem, antropólogos que falem nossa língua. Precisamos de antropólogos que venham nos trazer notícias do que os brancos estão fazendo, do que o governo está dizendo, do que os-governos estrangeiros estão dizendo" (KOPENAWA, 2010, p. 530). Here, Kopenawa is alluding to the breadth of responsibility inherent in an anthropological pact. The ethnographer has to become a truchement, speaking to the indigenous about his opaque world, and speaking to that world, to which he has a certain institutional access, about the indigenous, such that the latter gain a form of "reconhecimento e cidadania no mundo opaco e virulento que se esforça por sujeitá-los" (KOPENAWA, 2010, p.522).
} 
conceived. If Kopenawa, as Gow points out, does not aim to convert us to his own cultural practices, he does want us to reflect on the transformative in-between space opened up by shamanism, anthropology, and listening: "A meu ver, só poderemos nos tornar brancos no dia em que eles mesmos se transformarem em Yanomami" (KOPENAWA, 2010, p.75). What would it mean to become Yanomami? To listen to the voice of the other within ourselves? There is a parallel to the kind of listening that Alice in Wonderland engages in. Born of another kind of anthropological experiment-the friendship between adult and child-it ends up bearing a similar sense of bi-directional becoming, of virar outro as the ultimate source of generation. In both cases, listening to the other necessitates the opening up of new cultural spaces. Within Kopenawa's text, neither the reader nor the author is comfortably situated in self: Davi, the Yanomami, inhabits our textual space so that we, the reader, can learn to listen to a text.

Beginning in his introductory reflection on why he has produced this text, "Palavras dadas," Kopenawa pushes the form of textuality beyond "reading". If he has chosen to fix Yanomami words into the "peles de imagens" of the whites, this change in Yanomami shamanic practices is about opening a new possible listening: "minha fala será algo de novo, para aqueles que a quiserem escutar" (KOPENAWA, 2010, p.64). Kopenawa hopes that the reader, by listening to his words, may open up to a new orientation vis-à-vis the future: "Os brancos não pensam muito adiante no futuro. Sempre estão preocupados demais com as coisas do momento. É por isso que eu gostaria que eles ouvissem minhas palavras através dos desenhos que você fez delas" (KOPENAWA, 2010, p.64). Kopenawa's text, like all words from Omama, thus presents the double-structure of becoming by turning toward the future: "Quero também que os filhos e filhas deles entendam nossas palavras e fiquem amigos dos nossos, para que não cresçam na ignorância" (KOPENAWA, 2010, p.65). If this attempt at Yanomami textuality is new with respect to the Yanomami tradition, the format and content of the text is also new within Western anthropology. ${ }^{9}$ It is no wonder, then, that the bi-directional becoming should extend into the realm of authorship become intersubjectivity and readership become listening. Certainly, we should be careful not to conceive of this text as an unmediated presence in which

\footnotetext{
${ }^{9}$ See Bruce Albert's note on this point in the prologue (50). In assuming part of the text's dual authorship, Albert refuses to be a "ghost editor," in the vein of classical "ethnobiography," in which anthropologists reconstruct a life narrative from several interviews, without actually transcribing the indigenous "author's" own words.
}

Eutomia, Recife, 25(1): 1-16, Dez. 2019 
Kopenawa's voice surges forth and we hear it. ${ }^{10}$ Rather, we can ask what it means for these transcribed recordings to be "heard" by Western readers. ${ }^{11}$ What listening practice allows us to hear the ever-present surrounding of the forest, and to let its meaning proliferate through us?

II.

In order to access Omama's words, Kopenawa had to learn listen to the non-human voices of the xapiri in a dissociative shamanic initiation he calls virar outro, which follows a Yanomami tradition. ${ }^{12}$ Though this practice encompasses all the senses (and indeed, all sense), I want to read several passages that emphasize what, following Bernd Brabec de Mori, I call "sonic perspectivism." This is an interpretive angle, adopted by anthropologists toward Amazonian indigenous cultures, that emphasizes how audio processes undergird different perspectival transformations that allow for communication across disparity. ${ }^{13}$

To set the stage of Kopenawa's shamanic initiation, we must reflect on the meaning of the word "initiation" itself. This is a scene of birth, of origins. Physically swaddled by the spirits, "como um bebê", Kopenawa is also born into a kind of originary listening, a listening that is itself reborn every time throughout his life as a shaman that he makes contact with the xapiri and renews their words (KOPENAWA, 2010, p.142). How does the time of Omama come to bear on the text? The recitation of the initiation inhabits the text cyclically-that is, the same basic experience is retold and renewed several times.

In Davi's narration of his initiation process, he notes that silence is absolutely necessary in order for the xapiri to begin to sing to him. ${ }^{14}$ After days of nutritional deprivation and inhalation of the yãkoana, Davi still sees no xapiri, and begins to worry. His father-in-law, and initiator, teaches him how to hear:

Então, agachado ao meu lado, o pai de minha esposa começou a me ensinar a ouvir os cantos dos espíritos. Dizia: "Se você quer mesmo tornar-se xamã, deve

\footnotetext{
${ }^{10}$ Gow warns against conceiving of indigenous speech as a practice of unmediated presence (GOW, 1995, p.56).

11 This "normal" conception of textuality would refer to an encoding and decoding practice, which Tim Ingold explains as follows: "Para o leitor moderno ocidental, o papel não é mais do que uma superfície sobre a qual se projetam imagens gráficas de sons verbais" (LIBRANDI, 2012, p.199).

12 "Sem virar outro, mantendo-se vigoroso e preocupado com o que nos cerca, seria impossível ver as coisas como os espíritos as veem" (KOPENAWA, 2010, p.141).

${ }^{13}$ See Brabec de Mori pp. 96-97.

14 "Tudo devia permanecer silencioso ao meu redor" (KOPENAWA, 2010, p.137).
}

Eutomia, Recife, 25(1): 1-16, Dez. 2019 
responder à voz deles imitando seus cantos e falando com eles. É claro que no começo você não vai conseguir. Mas, aos poucos, eles vão the revelar suas palavras. Sua boca não deve ter medo! (KOPENAWA, 2010, p.147)

This is the "foretelling," by his father-in-law, whose mentorship and participation in Kopenawa and Albert's work is another layer of mediation, translation and collaboration structuring the text, and giving spiritual priority to the elders before the initiates. In the father-in-law's explanation, the first act of the listening begins with an imitative response, as if one's own voice and the voice one was imitating were indistinguishable. We could call this the originary selfothering operated by resonant listening, which begins with voice and ear in indistinguishable concert. Listening is prior to the distinction between passive and active, silence and singing, hearing and imitation.

Here is the second sonic initiation:

Então, de tanto prestar atenção, comecei a poder ouvir as palavras dos espíritos. Eles trocaram minha língua e minha garganta pelas deles. E assim, aos poucos, seus cantos foram se revelando a mim e se tornando claros. Comecei a cantar como eles. Mas foi tudo muito devagar. Não se pode ser impaciente nesse caso. Deve-se tentar pouco a pouco imitar a última parte das palavras do canto dos espíritos. É assim que se consegue começar a escutá-los de verdade [...]. (KOPENAWA, 2010, p.148)

Undergirding the shamanic initiating is a mutual becoming other between the self and the spirits. Davi's mouth, rid of its fear, is now traded part for part with the body of the spirits, who will eventually come to build their houses inside his stomach. ${ }^{15}$ In learning to echo the spirits, Davi is adopting the same self-transformative virar outro structure that the xapiri permanently inhabit. ${ }^{16}$ The order of operations here, where imitation precedes and ushers in the escutar de verdade, is another manifestation of the undecidable temporality of shamanic becoming. The

\footnotetext{
${ }^{15}$ Viveiros de Castro "The Forest of Mirrors" essay contains a litany of ways in which the shaman in various Amazonian cultures and the spirit share characteristics of liminality between animal, human, and immortal worlds. He writes that "shamans - humans or animals, since non-human species also possess shamans - are the only beings that 'retain the primitive characteristics from before the separation between humans and animals'" (VIVEIROS DE CASTRO, 2010).

${ }^{16}$ Viveiros de Castro explains this structure in terms of ceaseless transformation: "it is this self-difference which defines a 'spirit,' and which makes all mythic beings into 'spirits' too. The supposed 'indifferentiation' between mythic subjects is a function of their radical irreducibility to fixed essences or identities, whether these are generic, specific, or individual" (VIVEIROS DE CASTRO 2010).
} 
effort to listen begins with the transformation of the body, followed by the revelation of the song, followed by the effort to imitate, followed finally by "beginning to truly listen to the xapiri." The first action is last, and the last is first, or perhaps, all the actions happen in a simultaneous moment of becoming.

Jean-Luc Nancy writes that profound listening, directed at the otherness within oneself, contains within it the generative moment inherent to birth:

Someone who comes to himself by hearing himself cry (answering the other? calling him?), or sing, always each time, beneath each word, crying or singing, exclaiming as he did by coming into the world... the birthing cry, birth of the cry-call or complaint, song, rustling of self, until the last murmur. (NANCY, 2007, pp.27-28)

Kopenawa's text insists on this moment of hearing the other cry within himself by cycling back repeatedly to the birthing cry. This dual passive-active structure of listening/singing undergirds other Amazonian listening practices, including the Kamayurá of the Xingu, as Menezes Bastos explains: "Note-se aí a ideia talvez mais básica da percepção entre esses índios, como simultaneamente ativa e passiva. Quer dizer, para esses índios ouvir significa ao mesmo tempo receber sons e ativamente captá-los" (NANCY, 2007, p.5). In this reflexive call-and-response, Davi's position remains prior to caller or responder, and encompasses both, as he repeats for a third time this sustained reflection on originary listening:

Aí é preciso se esforçar para responder, para que fiquem felizes de nos escutar e nos incentivem com seus clamores. Foi assim que, apesar de todo o medo, comecei a cantar. Ainda só percebia sonoridades muito fracas. Apesar disso, decidi responder à voz dos xapiri, ecoando-a. [...] Então retomavam seus cantos, subindo o tom de suas vozes mais e mais. Foi assim que, por fim, consegui ouvilos de verdade e cantar como eles. (KOPENAWA, 2010, pp.148-9)

If the last passage concluded with the discovery of "truly listening" (escutar de verdade), this one concludes with "truly hearing" (ouvi-los de verdade). The listening that broached the initiation is like a promise that the hearing fulfils.

III.

Eutomia, Recife, 25(1): 1-16, Dez. 2019 
These passages detail the cyclic apprenticeship in listening, where beginning and end are inverted and initiation is repeated and repeatable, and ultimately merges with the project of shamanic renewal that undergirds the text. The sonic meeting with the xapiri parallels the visual meeting, in which the spirits are always mirrored, reflecting a proliferation of meaning, its suppleness and generativity. Viveiros de Castro glosses mirrors as manifestations of an "endlessly proliferating, always abundant, infinitely extensible world" (VIVEIROS DE CASTRO, 2010). The mirror, like Davi's study of resonance, obscures the question of the origin by referring infinitely back. This infinite reference is the same structure Deleuze points out about Alice's mirror:

Des deux séries qu'elle anime, on ne dira pas que l'une soit originaire et l'autre. Certes elles peuvent être originaire ou dérivée l'une par rapport à l'autre. Elles peuvent être successives l'une par rapport à l'autre. Mais elles sont strictement simultanées par rapport à l'instance où elles communiquent. (DELEUZE, 1969, p.55)

The mirror structure captures the way Kopenawa is certainly not the originary voice he echoes, yet his imitation is itself indistinguishable from the sound from which it derives. It is an echo, an original derivation. Shamanic listening is the proliferating instance of communication between separate worlds, when the derived returns to the original and allows for the condensation of new meanings.

Listening provides the very basis upon which the shamans build a sense-making, sensible, sensing world. The experience of the alter-ego in the echo, of the listening prior to active/passive distinctions, is the experience of the base upon which meaning is made. First of all, listening is, as Nancy argues, the base element of sense: "Listening aims at-or is aroused by-the one where sound and sense mix together and resonate in each other, or through each other. (Which signifies that... if, on the one hand, sense is sought in sound, on the other hand, sound, resonance, is also looked for in sense.)" (NANCY, 2007, p.7) Secondly, as Viveiros de Castro argues, the xapiri are "the very stuff of sense... they are the ones who answer for the meaning of the world" (VIVEIROS DE CASTRO, 2010). This is why the initiation into the multinatured life of the xapiri is simultaneously an initiation into the deep meaning of listening. Both listening and the xapiri are the experience of what it is to mean.

Eutomia, Recife, 25(1): 1-16, Dez. 2019 
In the last instance, the song of the xapiri is contingent on the forest. Sense and the possibility of listening depend on the health of the forest, its ability to regenerate. The forest means (or rather, it "wants to tell" (quer dizer)). It does not mean nothing. As Kopenawa points out in the "Palavras dadas": "Gostaria que os brancos parassem de pensar que nossa floresta é morta e que ela foi posta lá à toa. Quero fazê-los escutar a voz dos xapiri... Quem sabe assim eles queiram defendê-la conosco" (KOPENAWA, 2010, p.65)? If Davi's experience highlights certain creative properties inherent in listening in general, it is crucial to recognize that the richness of his experience, in terms of temporal depth (stretching back to the primeiros tempos), collective ecological knowledges, and cosmopolitical counter-colonial politics are predicated upon the now-more-than-ever precarious existence of the Yanomami within their section of the central Amazon. Édouard Glissant's famous adage "Agis ton lieu, pense avec le monde," comes to mind here: the bi-directional becoming structure of Kopenawa's shamanic listening, which may be read as universal, depends on the specificity of place. The urgent message about listening as the foundation of meaning-making is part of Kopenawa's cosmopolitical project, that is, the possibility of a shared fight to defend the forest. ${ }^{17}$ By offering his words to a wider readership (listenership?), Kopenawa expands the sense of the term forest, and the grounds of the struggle. ${ }^{18}$

Throughout the text, Kopenawa describes the forest's meaning in terms of silence. In this sense, we ought to consider the entire "listening lesson" as a reflection on the creative potential of truly listening to silence, or what Nancy calls the "telling silence ${ }^{\prime \prime}{ }^{19}$ While the whites are sleeping without dreaming, he says, "no silêncio da floresta, nós, xamãs, bebemos o pó das árvores yãkoana hi, que é o alimento dos xapiri... Por isso somos capazes de ouvir seus cantos" (KOPENAWA, 2010, p.76-77). Merleau-Ponty argues that we have forgotten the way meaning originates in the unknown of our own corporeal experience-that is, in silence: "Notre

\footnotetext{
${ }^{17}$ I borrow the term "cosmopolitical" from Albert's prologue (ALBERT, 2010, p.43). Indeed, Albert was one of the first whites to listen carefully to what Davi had to say. Listening continues to be his primary role (just as it is Davi's).

${ }^{18}$ As Viveiros de Castro points out, this means that the term "indigenous", and the struggle is as vast as the form of human life rooted in the earth: "Ser indígena é ter como referência primordial a relação com a terra em que nasceu ou onde se estabeleceu para fazer sua vida, seja ela uma aldeia na floresta, um vilarejo no sertão, uma comunidade de beira-rio ou uma favela nas periferias metropolitanas" (VIVEIROS DE CASTRO 2019).

${ }^{19}$ See Nancy on Lacan's "telling silence": "the space in which "I hear myself" when I grasp significations, when I hear them coming from the other or from my thoughts (which is the same thing). I can hear them, in fact, only if I listen to them resound "in me"" (NANCY, 2007, p.29).
} 
vue sur l'homme restera superficielle tant que nous ne remonterons pas à cette origine, tant que nous ne retrouverons pas, sous le bruit des paroles, le silence primordial, tant que nous ne décrirons pas le geste qui rompt le silence" (MERLEAU-PONTY, 2004, p.224). We can understand A Queda do céu as itself a "gesture that breaks the [Western] silence" about Yanomami meaning. Yet this gesture depends on a prior shamanic initiation that touches the "primordial silence." Kopenawa's text is thus an open question for readers: how far can this creative listening born of the forest proliferate?

IV.

In Kopenawa's text, the silent forest contrasts with the noisy city. Noise, according to Valéry, is what cannot be organized into an intelligible system: it only refers to whatever produced it; and it has no other meaning. Its meaning is arbitrary (quoted in NANCY, 2007, p.15). This reflects Kopenawa's auditory experience of the city, where noise proliferates and clouds the meaning of words. "O barulho contínuo e a fumaça que cobre tudo impedem de pensar direito. Deve ser mesmo por isso que os brancos não conseguem nos ouvir" (KOPENAWA, 2010, p.435). Noise is connected to the senseless world governed by money's abstract equivalence, where hearing has become impossible.

Kopenawa's description of the invention of money among the whites, and its spread by "imitation," is the reverse process of the listening lesson of his shamanic initiation:

Todos os brancos acabaram por imitar o mesmo jeito. E assim as palavras das mercadorias e do dinheiro se espalharam por toda a terra de seus ancestrais... Foi com essas palavras da mercadoria que os brancos se puseram a cortar todas as árvores, a maltratar a terra e a sujar os rios. (KOPENAWA, 2010, p.407)

The spread of market capitalism, before any material change, is an imitation of a certain market language. If the words of the forest proliferate with meaning, the words of the market are at their origin absurd. Far from connecting to the regeneration of the forest, they are its destruction. And without this regenerative base, all the whites hear is "o ruído de seus aviões, carros, rádios, televisores e máquinas. Por isso suas ideias costumam ser obstruídas e enfumaçadas" (KOPENAWA, 2010, p.76). The smoke that obscures thought is the visual equivalent of noise. Just as noise opposes silence, smoke opposes mirroring. From the very 
title, Kopenawa's text warns that the proliferation of noise and the failure to listen can bring about nonsense-the return of chaos to the world.

As we have seen, Yanomami forest generates sense, and the Yanomami language is impregnated with the temporal depth of that sense. An objective view of language, which disconnects the sign—calling it an arbitrary sound-from meaning would not make sense within Yanomami cosmology. As Kopenawa explains, a word, even when it takes on a new sense, keeps the old ones and the powers associated with them. The word matihi, which the Yanomami now use to speak of industrial commodities, keeps the power of other associations, including Omama's goods, and the remains of the dead. ${ }^{20}$ Matihi is not arbitrary, but grounded in the meaning made by the ancestors, and renovated in its reuse to describe commodities. It is the way the Yanomami maintain power over commodity, instead of yielding to its dominance and ushering in capitalism: "Não é à toa que chamamos as cinzas e os ossos de nossos mortos de matihi! Nossos antepassados nos deram essa palavra poderosa, porque o valor que damos a essas coisas é maior até do que o que os brancos dão ao ouro que tanto cobiçam" (KOPENAWA, 2010, p.409). In calling matihi more valuable than what the whites consider gold to be, Kopenawa declares the ontological priority of his specific community over money's abstraction and affirms the way the Yanomami have incorporated the invasive commodities of market capitalism within an ethics of intersubjective care. The word matihi is central to a "counter-modern" system of exchange. The Yanomami give matihi to those who need them, building bonds that hold into the future. When someone who owns matihi dies, the Yanomami cease to exchange their objects, instead burying them along with the dead. The connection to the collective past overrides the commodity's utility and prevents it from dominating social life.

This system is inextricably related to the listening practice discussed earlier. If the Yanomami did not "receive" (in that form of listening that is both active and passive) the word matihi from their ancestors, and try to renew it, would the system itself exist? There is no way to tell which came first, word or practice. Both are born out of the agitation of a situation in which the outside is pressing in. This is what Merleau-Ponty refers to as "living language,"

\footnotetext{
${ }^{20}$ Kopenawa describes the word as "muito valiosa", giving it the "valor de espírito" because it evokes "a beleza dos xapiri" and as having a "força" (KOPENAWA, 2010, p.408). This relationship with words as material is not far from that of many poets in industrial societies, as Marília Librandi points out (see p. 199).
}

Eutomia, Recife, 25(1): 1-16, Dez. 2019 
which is "La langue présente dans une communauté linguistique qui s'en sert non seulement pour conserver, mais encore pour fonder, pour viser et définir un avenir" (MERLEAU-PONTY, 1960, p.131). What is born is an institution, at once a new meaning and a new way of being, foundational but also founded by past practices and language.

V.

As much as this text is a history of the birth of listening, it is also tragic in tenor. Omama's words, carried by Kopenawa's rage, come out of the forest and into a text (texts which are themselves "arvores mortas") because market capitalism has entered there, leaving a trail of destruction in its wake (KOPENAWA, 2010, p.66). The text oscillates between the title and the subtitle, between A Queda do céu and Palavras de um xamã yanomami, and likewise between despair and hope, deafness and listening. This is the modern shamanic between: between morning and mourning-that is, between the jubilant song of initiation, and the lament of the xapiri: "Ouvi muitas vezes suas vozes lamentarem, enquanto eles levavam minha imagem às lonjuras para me mostrar a devastação" (KOPENAWA, 2010, p.328). This text, engaged in the form of mediation (writing) that was a primary tool of the conquest of the Americas and spread of world capitalism, seeks to found within textuality itself a difference, a split, a form of becoming that is named virar outro. It takes part in a battle of what Viveiros de Castro terms the "absolute contemporaneity" of modern capitalism and counter-modern indigeneity (VIVEIROS DE CASTRO, 2010, p.32). It is literally founded on Kopenawa's outrage at televised images of the destruction of the earth, generated out of that destruction. The cyclic movement between the two titles reflects the text's deep structure, in which the in-depth exploration of the renewal of Omama's words is presented in order to mobilize the readers of the world in the name of sense against the market's nonsense. Ultimately, the call to listen is a call-to-arms.

This text is a foundational gesture: the words of Omama are for the first time available to readers. Its generation is itself a message about shamanism as diplomacy-translation, mediation, and renewal: from Omama, to the xapiri, to the Yanomami ancestors, to his elders and father-in-law, to Kopenawa himself, to Albert, translated again, we have a chain of 
listening whose ultimate destination, Kopenawa hopes, is our children. From the forest's past, the concern is the world's future.

\section{Cited references}

Brabec de Mori, Bernd. "About magical singing, sonic perspectives, ambient multinatures, and the conscious experience." Indiana (29), 2012, 73-101.

Deleuze, Gilles. Logique du sens. Minuit, 1969.

Gow, Peter. "'Listen to me, listen to me, listen to me, listen to me...': A brief commentary on The falling sky by Davi Kopenawa and Bruce Albert." HAU: Journal of Ethnographic Theory. (4:2) 2014, 301-309.

_ . "Land, People, and Paper in Western Amazonia." The Anthropology of Landscape. Eds. Eric Hirsch and Michael O'Hanlon. Clarendon Press, 1995.

Kopenawa, Davi and Bruce Albert. A Queda do céu: Palavras de um xamã yanomami. Trans. Beatriz Perrone-Moisés. Companhia das Letras, 2010.

Librandi, Marília. "Escutar a Escrita: Por uma teoria literária ameríndia." O eixo e a roda. (21.2) 2012, 179-202.

Menezes Bastos, Rafael. "Audição do Mundo Apùap II - Conversando com "Animais", "Espíritos" e outros Seres. Ouvindo o Aparentemente Inaudível." Anthropologia em primeira mão. (134) 2012, 1-16.

Merleau-Ponty, Maurice. Phénoménologie de la perception. Gallimard, 2004.

Signes. Gallimard, 1960.

Nancy, Jean-Luc. Listening. Trans. Charlotte Mandell. Fordham University Press, 2007. Viveiros de Castro, Eduardo. "Os Involuntários da pátria." 2019. http://clinicand.com/2018/04/14/os-involuntarios-da-patria-por-eduardo-viveiros-de-castro/. Accessed 1/3/19.

- "The Forest of Mirrors. A few notes on the ontology of Amazonian spirits," 2010. http://amazone.wikia.com/wiki/The_Forest_of_Mirrors Accessed 12/18/18. 
' Doutorando, Departamento de Literatura Comparada, Princeton University.

E-mail: wmullaney@gmail.com

Eutomia, Recife, 25(1): 1-16, Dez. 2019 